\title{
Parabolic elements of the comet discovered
}

\section{Victor Mauvais}

To cite this article: M. Victor Mauvais (1844) Parabolic elements of the comet discovered, Philosophical Magazine Series 3, 25:165, 239-239, DOI: 10.1080/14786444408644980

To link to this article: http://dx.doi.org/10.1080/14786444408644980

曲 Published online: 30 Apr 2009.

Submit your article to this journal

Џ Article views: 2

Q View related articles $\sqsubset$ 
This liquor, when not strong, has the colour of weak tincture of litmus, but when concentrated it appears black; it remains clear for two or three days, but after this the oxide is entirely precipitated, and remains at the bottom of the vessel in the form of a blue cloud. The addition of a soluble salt to this liquor, when heated, occasions the instantaneous separation of the oxide, and a few drops of hydrochloric acid soon render it bright.

It does not always happen that distilled water produces the above described appearance, but the cause of the variation is not apparent; the mode of solution appears, however, to be similar to that of iodide of starch, prussian blue, \&c. \&c.--Ann. de Ch. et de Phys, Juillet 1844 .

PaRABolic ELEMENTS OF THE COMET DISCOVERED BY $M$. VICTOR MAUVAIS, JULY 7, 1844, AS COMPUTED BY HIMSELF.

Time of perihelion passage, October $1844 \quad 14.7681$ Paris mean time. Logarithm of perihelion distance ..... $9 \cdot 8817875(q=0.7617)$ Longitude of perihelion......... $176^{\circ} 35^{\prime} 42^{\prime \prime}$

Longitude of the ascending node..... $35 \quad 3742$

Inclination ................. 494123

Motion ................ retrograde

Comptes Rendus, 15 Juillet, 1844.

METEOROLOGICAL OBSERVATIONS FOR JULY 1844.

Chiswick.-July 1. Slight haze : cloudy: thunder, with rain from 6 till 8 P.sr. 2. Rain : cloudy. 3. Cloudy. 4. Slight rain: cloudy, 5, 6, Fine. 7. Hazy and mild : overcast. 8. Hazy: very fine. 9-11. Very fine, 12. Very fine: showery. 13. Rain : heavy rain at night. 14, 15. Clear and fine. 16. Overcast. 17. Fine : dusky clouds : hazy. 18. Very fine : cloudy. 19. Overcast : thunder quarter to 1 P.M. : thunder-showers in afternoon. 20, ?1. Clear and fine. 22. Cloudless and very hot. 23, 24. Sultry. 25. Very hot. 26. Cloudy: clear. 27. Hot and dry. 28. Very fine: cloudy. 29. Hot and very dry : exceedingly clear at night. 30. Overcast : rain. 3i. Cloudy and fine : clear.-Mean temperature of the month $1^{\circ}$ above the average.

Boston.-July 1. Fine : rain A.M. 2. Cloudy. 3. Fine. 4. Fine : rain P.M. 5. Rain. 6-8. Cloudy. 9-11. Fine. 12. Fine: rain $A, M$. 13. Fine : rain A.M. and P.M. 14. Stormy. 15. Fine: rain A.M., with thunder. J6. Fine : rain P.M. 17. Fine. 18. Fine: rain P.M., with thunder and lightning. 19. Fine: rain P. M. 20, 21. Fine. 22. Fine: thermometer $81^{\circ} 20^{\prime}$ clock P.M. 23. Fine :

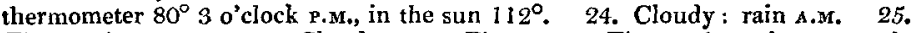
Fine : rain P.M. 26, 27. Cloudy. 28, Fine, 29. Fine: rain early A.m. : rain P.M. 30. Cloudy: rain P.M. 3I. Cloudy : rain, with thunder and lightning A.M.

Sandwick Manse, Orkney.-July 1. Cloudy. 2-6. Drizzle: showers. 7-9. Cloudy. 10. Cloudy : showers. 11. Showers: cloudy. 12. Damp: cloudy. 13. Bright: cloudy. 14. Cloudy. 15. Cloudy : clear, 16. Bright: clear. 17. Clear. 18. Clear : showers. 19. Cloudy : showers : drizzle. 20. Cloudy. 21. Cloudy : showers. 22. Cloudy : fine. 23. Clear: fine, 24. Bright: cloudy. 25. Clear: fine. 26. Clear: fog. 27. Clear: fine. 28. Bright: showers : fog. 29. Drizzle. 30. Cloudy. 31. Rain.

Applegarth Manse, Dumfries-shive.-July 1. Fine: a few drops of rain. 2-4. Fine : sultry. 5. Fine, but cloudy, 6. Slight shower. 7. Fine and fair. 8. Fine: a few drops of rain. 9. Fine, but cloudy. 10. Showers. 11. One shower. 12. A few drops of rain. 13. Heavy rain. 14. Showers : thunder. $15-17$. Showers. I8. Showers: thunder, 19. Slight shower: thunder. 20. Fair. 21. Wet all day. 22. Fine. 23. One heavy shower : thunder. 24-26. Rain : heavy P.M. 27. Beautiful day. 28. Showers. 29. Fair. 30, 31. Rain. 